\title{
融液の凝固過程におけるフッ素金雲母結晶の粒径 および形態制御
}

\author{
小島 康 寛* 松 尾 健 司** \\ 中島邦彦*** 森永健 次 ${ }^{* * *}$
}

J. Japan Inst. Metals, Vol. 55, No. 2 (1991), pp. 172-179

Control of Grain Size and Morphology of Fluor-phlogopite Crystals

in the Solidification of a Melt

Yasuhiro Kojima*, Kenji Matsuo**,

Kunihiko Nakashima*** and Kenji Morinaga***

On the basis of a TTT diagram during solidification of a melt in the system $\mathrm{SiO}_{2}-\mathrm{Al}_{2} \mathrm{O}_{3}-\mathrm{MgO}-\mathrm{MgF}_{2}-$ $\mathrm{K}_{2} \mathrm{O}-\mathrm{B}_{2} \mathrm{O}_{3}$, the effect of heat-treatment conditions on grain size, morphology and crystallization degree of fluor-phlogopite crystallized was discussed. By isothermal heat-treatment in the temperature range of 1253 to $1473 \mathrm{~K}$, fluor-phlogopite as spherical grains was crystallized directly from a super cooled liquid. On the other hand, below $1253 \mathrm{~K}$ spinodal decomposition type phase separation occurred as a prelude to the crystallization sequence. Energy dispersive X-ray analysis suggested that the growth rate of fluor-phlogopite crystals was controlled by diffusion of $\mathrm{Mg}$ ions. A linear relationship between the spinodal wave length and the plate diameter of fluor-phlogopite platelets was obtained as a result of the crystallization occurred in a Mg-rich phase.

(Received July 23, 1990)

Keywords: solidification, fuor-phlogopite, phase separation, grain size, morphology, timetemperature-transformation diagram

I ． 緒言

機械加工が可能なマイカセラミックスは，電気絶縁性に 優れ，熱膨張係数が金属に近いなどの特性を持つため，精 密加工の必要な電気, 電子部品の材料として用いられてい る(1).

マイカセラミックスの作製法にはフッ素雲母粉末の焼結 法 ${ }^{(2)}$ ，フッ素含有ガラスの結晶化法 ${ }^{(3)}$ 打よび融液の凝固 法(4)がある，焼結法によるマイカセラミックスでは内部に 残存する微細な気孔が構造欠陥となることが問題である ${ }^{(5)}$. ガラスの結晶化法により得られるマイカセラミックスは気 孔率がゼロと緻密であり，熱処理条件の設定により雲母結 晶の粒径を制御した例がある(3). しかし, 雲母結晶の晶出 機構やその結晶化率を制御する因子については明らかでな い。一方，融液の凝固法によるマイカセラミックスも緻密
であるが，これまでの報告では大きな単結晶を得ることが 主な目的であった ${ }^{(6)}$. 多結晶体については化学組成と微構 造との関係が検討されている(4) ものの，熱処理の条件を設 定し微構造を制御した例は少ない.

著者らは，先に CCT (連続冷却変態)図，TTT(時間-温 度-変態) 図の測定結果を基礎にフェロニッケルスラグの冷 却条件と組織の関係 ${ }^{(7)}$ や凝固過程におけるコーディエライ トセラミックスの相変態として, 特に $\boldsymbol{\mu}$ から $\alpha-$ コディ エライトへの変態機構 ${ }^{(8)}$ について検討した. 本研究では, フッ素金雲母を晶出させることが可能な融液の冷却・熱処 理過程に拈けるCCT 図およびTTT 図を作成し，フッ素 金雲母結晶の晶出に影響を及ぼすスピノーダル分解型分相 の存在温度範囲を明らかにした。さらに，TTT 図を基礎 に熱処理条件を設定しスピノーダル波長を制御することで 晶出するフッ素金雲母の粒径および形態を制御した。

* 九州大学大学院生, 現在 : 宇部化学工業(侏)(Graduate Student of Kyusyu University, Fukuoka. Present address: Ubekagakukougyou Ltd., Ube)

** 福岡工業短期大学電子情報学科 (Department of Electronics and Information Technology, Fukuoka Junior College of Technology, Fukuoka)

*** 九州大学大学院総合理工学研究科材料開発工学専攻 (Department of Materials Science and Technology, Graduate School of Engineering Science, Kyusyu University, Fukuoka) 


\section{II. 実験方法}

\section{1. 試料}

原料として $\mathrm{K}_{2} \mathrm{O}$ には特級炭酸塩を, $\mathrm{SiO}_{2}, \mathrm{Al}_{2} \mathrm{O}_{3}, \mathrm{MgO}$, $\mathrm{MgF}_{2}$ および $\mathrm{B}_{2} \mathrm{O}_{3}$ には特級試薬を用いた。試料として各 試薬を Table 1 に示した組成になるように秤量し，十分 混合した。試料は，フッ素金雲母の理論組成よりも $\mathrm{SiO}_{2}$, $\mathrm{Al}_{2} \mathrm{O}_{3}$ を過剩にし $\mathrm{MgO}, \mathrm{MgF}_{2}$ および $\mathrm{K}_{2} \mathrm{O}$ を減少させる とともに $\mathrm{B}_{2} \mathrm{O}_{3}$ を添加して, 結晶化速度が遅く微構造を制 御しやすい組成としている ${ }^{(9)(10)}$.

Table 1 Sample composition (mol\%).

\begin{tabular}{c|c}
\hline \hline Material & Composition (mol\%) \\
\hline $\mathrm{SiO}_{2}$ & 48.2 \\
$\mathrm{Al}_{2} \mathrm{O}_{3}$ & 9.8 \\
$\mathrm{MgO}^{\mathrm{MgF}}$ & 19.2 \\
$\mathrm{~K}_{2} \mathrm{O}$ & 7.4 \\
$\mathrm{~B}_{2} \mathrm{O}_{3}$ & 6.7 \\
\hline
\end{tabular}

\section{2. 熱処理}

1 回に溶融させる試料量は $2.0 \times 10^{-2} \mathrm{~kg}$ とした. 蓋付 きの白金ルツボに充填した試料粉末を $723 \mathrm{~K} に$ 保持した $1.33 \times 10^{-1} \mathrm{~Pa}$ 程度の真空容器中で $3.6 \mathrm{ks}$ 間乾燥させるこ とで十分脱水した後, 脱水アルゴン雲囲気において 1723 $\mathrm{K}$ で $1.8 \mathrm{ks}$ 間溶融した.

CCT 図を作成するための熱処理は, 溶融試料を 0.05 , $0.2,1.5$ および $50 \mathrm{~K} / \mathrm{s}$ の冷却速度で連続冷却することによ って行った，TTT 図を作成するための熱処理は，溶融試 料を予め所定の温度に設定した電気炉にすばやく移し, 所 定の時間脱水アルゴン雲囲気中で等温熱処理した後, ルッ ボごと氷上に急冷することにより行った．溶融試料を等温 保持用の電気炉に移動させる際に結晶化することはなく, 設定した保持温度との誤差範囲は $\pm 5 \mathrm{~K}$ 程度であった。な お, 等温保持の開始時間は溶融試料を初めの電気炉から取 り出した時点とした．TTT 図を作成するための等温熱処 理は $25 \mathrm{~K}$ 間隔で10回ずつ行い, 後述する結晶化率として は10個の試料についての平均値をとった。

熱処理後の各試料については粉末 X 線回折法による結 晶相の同定と結晶化率の測定および走査型電子顕微鏡によ る組織観察を行った.

粉末 X 線回折にはフッ素金雲母結晶の配向性の影響が ないよらに $40 \mu \mathrm{m}$ 以下に粉砕した粉末を用いた。また， 結晶化率の測定にはX 線回折による内部標準法(7)(11)を用 いた，検量線を作成するために結晶化率既知の試料を以下 の方法で調整した。結晶化率 $0 \%$ の試料としてのガラスは 試料を溶融した後水上に急冷することで作製した．結晶化
率100\%の試料としては，フッ素金雲母組成の混合粉末を 前述の条件で真空乾燥し，脱水アルゴン雾囲気において $1773 \mathrm{~K}$ で $1.8 \mathrm{ks}$ 間溶融した後 $1373 \mathrm{~K}$ で $10.8 \mathrm{ks}$ 間等温 熱処理し完全に結晶化させたものを作製した。これらの試 料を $40 \mu \mathrm{m}$ 以下に粉砕した後，所定の割合に秤量し，混 合したものを用いて結晶化率の異なる試料を調整した。検 量線は，結晶化率既知の試料に内部標準物質として 5 mass $\% \mathrm{Cu}$ を添加した試料の X 線回折図を用いて，フッ 素金雲母の主ピークの強度 $\left(I_{001}\right)$ と $\mathrm{Cu}$ の主ピークの強度 $\left(I_{\mathrm{Cu}}\right)$ との比 $\left(I_{001} / I_{\mathrm{Cu}}\right)$ により作成した。なお，用いた X 線 回折装置は理学電機製の MJ210EX2 で, $\mathrm{CuK} \alpha$ 線により 管電圧 $35 \mathrm{mV}$ ，管電流 $15 \mathrm{~mA}$ の条件で $2 \theta=5^{\circ} \sim 70^{\circ}$ の範 囲で測定した.

試料の組織観察に用いた走査型電子顕微鏡は日本電子製 の JXA-840である。組織観察には表面を鏡面仕上げした 後， $5 \% \mathrm{HF}$ 溶液でェッチングした試料を用いた。をた， エネルギー分散型 X 線分析装置 $(\mathrm{EDAX}$; 堀場製作所製, EMAX-1700)を用いて，組成分析を行った。

\section{III. 結 果}

\section{1. フッ素の揮発}

田草川ら (12) は $\mathrm{K}_{2} \mathrm{O}-\mathrm{MgO}-\mathrm{MgF}_{2}-\mathrm{SiO}_{2}$ 系の試料を 1673 $\mathrm{K}$ で $3.6 \mathrm{ks}$ 間溶融後, 急冷してガラスを作製した際にフ ッ素の揮発量は添加量の約 $8 \%$ であり, 揮発量の約 $4 / 5$ は $\mathrm{SiF}_{4}$ として揮発し, 残りの約 $1 / 5$ は $\mathrm{KF}$ や $\mathrm{HF}$ として揮 発すると報告している。 また，森永ら ${ }^{(13)}$ は $\mathrm{CaO}-\mathrm{Al}_{2} \mathrm{O}_{3}$ $\mathrm{CaF}_{2}$ 系融体に拈ける $\mathrm{HF}$ とてのフッ素の揮発は, 試料 中の付着水と䨌囲気の水分を十分に除去することにより防 止できるため, $\mathrm{AlF}_{3}$ としてのフッ素の揮発のみを考慮す ればよいと報告している.

本研究では試料中および雾囲気中の水分は十分に除去し ているため, HF としてのフッ素の揮発はないと考えられ る. Table 1 に示した試料組成より，質量換算でフッ素の

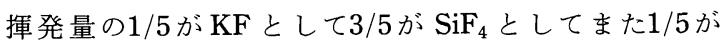
$\mathrm{AlF}_{3}$ として揮発したと仮定し, 試料の質量減少から揮発 したフッ素の割合を求めた. その結果, 熱処理の際に揮発 したフッ素の割合は $8 \pm 2 \%$ 範囲であった。ただし，熱 処理温度が $1473 \mathrm{~K}$ 以上になるとフッ素金雲母の分解温度 領域(14)になるためフッ素の揮発量は著しく増加した。

\section{CCT (連続冷却変態)図}

Fig. 1 亿試料組成の融液を室温まで所定の冷却速度で 連続冷却した試料の X 線回折結果から作成した CCT 図を 示す。な拉，図中に試料組成を表示した。冷却時に 1473 $\mathrm{K}$ 以上の高温領域で長時間保持した場合の結果は，フッ 素の揮発量が多くなり速やかに冷却した状態とは組成が異 なるため，破線で示した。 ガラス化のための臨界冷却速度 は約 $1.5 \mathrm{~K} / \mathrm{s}$ であり, $1.5 \mathrm{~K} / \mathrm{s}$ より速い冷却速度で泠却し 


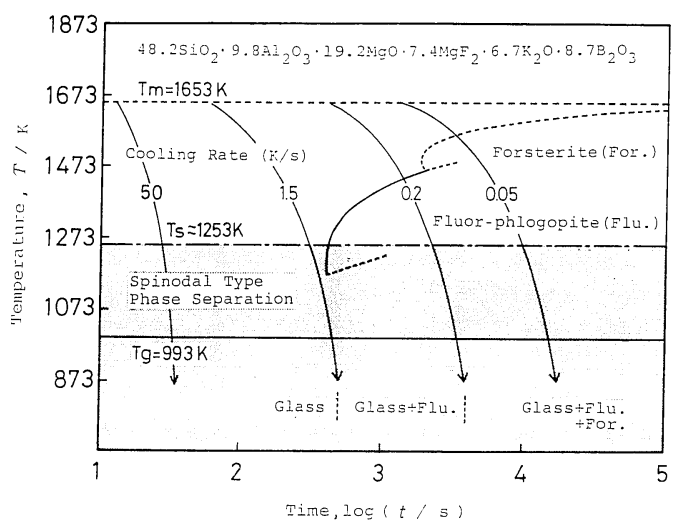

Fig. 1 CCT diagram.

た場合には白濁した分相ガラスが得られる．この分相ガラ スは組織観察の結果から, 絡み合い構造を示し, スピノ一 ダル分解型分相ガラスであった。なお， $50 \mathrm{~K} / \mathrm{s}$ (水上に急 冷) して得られるガラスは見かけ上は透明な，分相ガラス である. $1.5 〜 0.2 \mathrm{~K} / \mathrm{s}$ の冷却速度で冷却した場合はフッ 素金雲母が晶出するが結晶粒径が数十 $\mu \mathrm{m}$ と大きく，その 晶出量も少量で残部は分相ガラスであった。ささらに, $0.2 \mathrm{~K} / \mathrm{s}$ よりも遅い冷却速度で冷却した場合はフッ素金雲 母以外にフォルステライトが晶出し, 冷却速度が遅くなる につれてフォルステライトの晶出量が増大し, 残存する分 相ガラス相の量は減少した。 なお, 本研究での冷却速度範 囲内ではFig. 1 中に示した結晶相以外の結晶は同定され なかった。

以上のように試料組成の融液を連続的に室温まで冷却し た場合にはスピノーダル分解型分相の生成を避けることは できない，フッ素金雲母結晶の結晶化率を上げるためには 分相の生成領域以上の温度で結晶化を進めるように徐冷却 すればよいが，結晶が粗大化する傾向にあった。

\section{3. $\mathbf{T T T}$ (温度-時間-変態)図}

Fig. 2 にTTT 図を示す。図中の結晶化曲線はX 線回 折により結晶の晶出が確認された熱処理の温度と時間によ り決定している。 また，分相領域は試料の組織を観察した 結果から分相が確認された熱処理の温度と時間により決定 した.フッ素の揮発量が多い $1473 \mathrm{~K}$ 以上の高温領域にお ける結果は, 前述と同様の理由から破線で示した。

結晶化曲線は高温 (約 $1473 \mathrm{~K}$ ) と低温(約 $1273 \mathrm{~K}$ )にノー ズをもつ 2 つ C 曲線で表わされた. $1473 \mathrm{~K}$ 以上ではフ ッ素金雲母は生成せずフォルステライトが晶出し，1473 $\mathrm{K}$ 以下ではフッ素金雲母が晶出している. $1253 \mathrm{~K}$ 以下に はスピノーダル分解型分相の領域が存在しており, この温 度領域で等温熱処理をすると保持とともに分相が成長した 後結晶化する. 本研究での熱処理時間内 $(86.4 \mathrm{ks}$ 間)では Fig. 2 中に示したフッ素金雲母敃びフォルステライト以

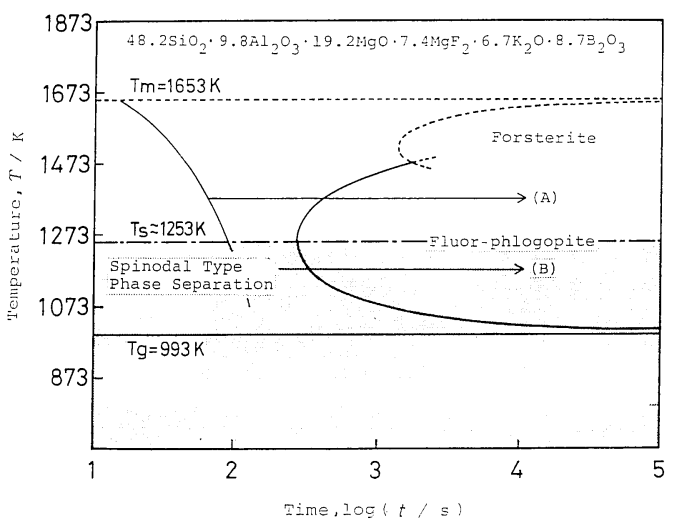

Fig. 2 TTT diagram.

外の結晶相は同定されなかった。

このよらに目的のフッ素金雲母結晶を等温熱処理により 得る条件としては $1473 \mathrm{~K}$ 以上で過冷却液体より直接晶出 させる場合と $1473 \mathrm{~K}$ 以下でスピノーダル分解型分相が生 じた後晶出させる場合がある．以下では TTT 図を基にフ ッ素金雲母結晶の粒径制御を検討する.

\section{TTT 図を用いた熱処理と組織および結晶化率との 関係}

Fig. 3 に, Fig. 2 中に示した(A)，(B)の熱処理を施し た試料の組織写真を示す。熱処理 $(\mathrm{A})$ のように融液を速や かに過冷却液体状態へ冷却した後分相の温度領域以上であ る $1373 \mathrm{~K}$ で等温熱処理した試料では，Fig. 3(a)，(b) 抒 よび(c)からわかるよらに核生成-成長により生じたフッ素 金雲母の球状粒子が熱処理時間の経過とともに連結-合体 し柱状結晶に成長していく過程が観察される. 一方, 熱処 理(B)のように分相の温度領域内である $1173 \mathrm{~K}$ で等温熱 処理した試料では，Fig. 3 (d)，(e)および(f)からわかるよ らに，まずスピノーダル分解型分相が出現し，矢印で示す ように分相のマトリックス側にフッ素金雲母が晶出し時間 とともに成長し, $10.8 \mathrm{ks}$ 間等温熱処理した試料(Fig. 3(f)) ではフッ素金雲母の板状結晶が分相界面により分断された 状態が明確に観察される.

Fig. 4 に, Fig. 3(d)および(f)に示した組織について EDAXにより組成分析を行った結果を示す．ただし，軽 元素である B, O, Fについては分析していない. Fig. 4(a) に示すよらにこのスピノーダル型分相は $\mathrm{Mg}$ の含有量が 異なるA, B 相から成っている. Fig. 4(b)からは, Mgの 含有量が多い $\mathrm{A}$ 相からフッ素金雲母結晶が晶出している ことがわかる.

Fig. 5 に結晶化率測定に用いた検量線を示す. 図から わかるようにフッ素金雲母の結晶化率と $I_{001} / I_{\mathrm{Cu}}$ との間に は直線関係が成立することから, この検量線を用いて後述 するフッ素金雲母の結晶化率を決定した。 

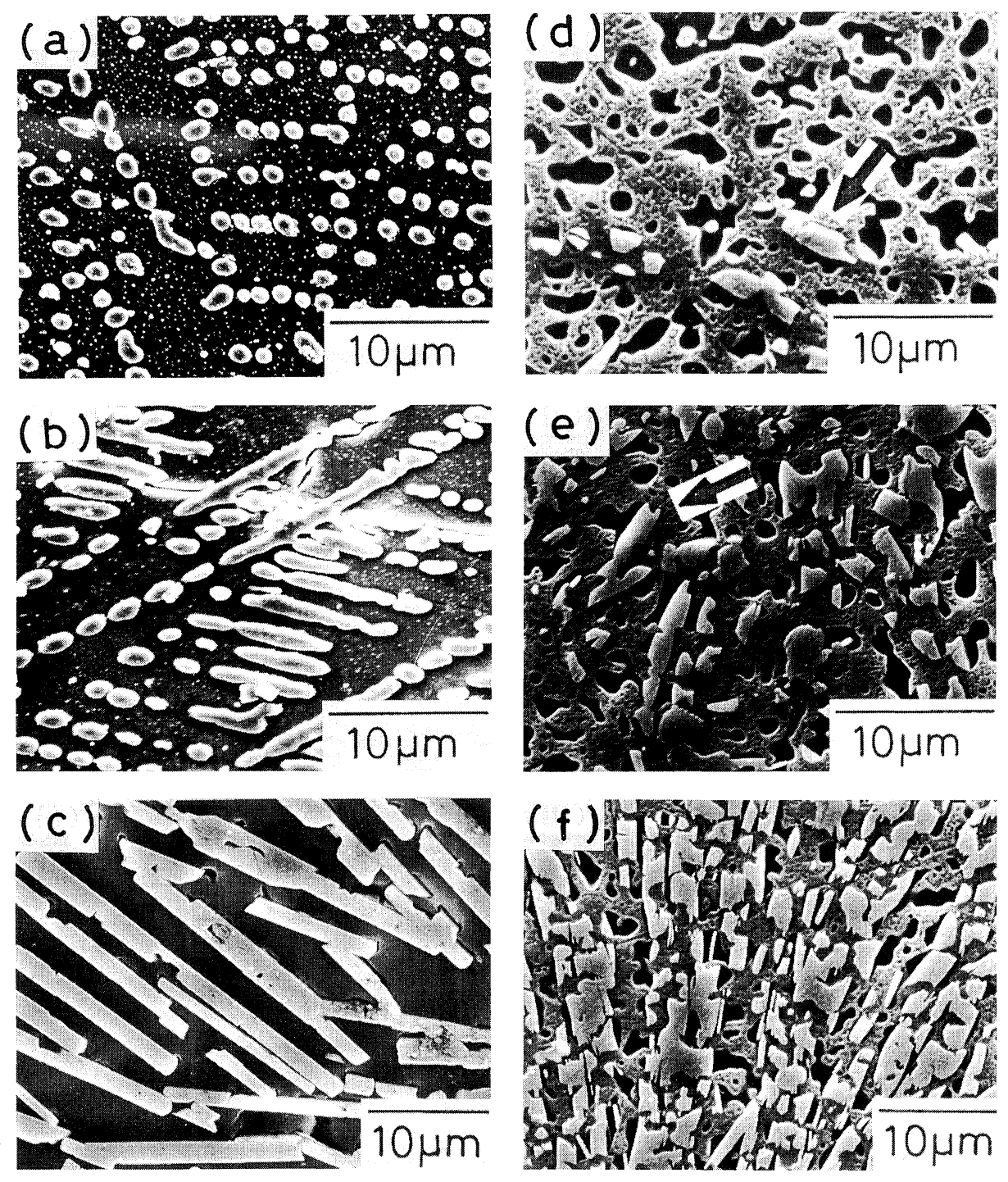

Fig. 3 SEM photographs of sample structures illustrating the effect of isothermal heat-treatments, (A) and (B) shown in Fig. 2. (A): held at $1373 \mathrm{~K}$ for (a) $0.6 \mathrm{ks}$ (b) $1.8 \mathrm{ks}$ and (c) $10.8 \mathrm{ks}$. (B): held at $1173 \mathrm{~K}$ for (d) $0.6 \mathrm{ks}$, (e) $0.7 \mathrm{ks}$ and $(\mathrm{f}) 10.8 \mathrm{ks}$.

Fig. 6 に, Fig. 2 中に示した(A), (B)の熱処理を施し た試料におけるフッ素金雲母の結晶化率の経時変化を示 す. 熱処理 $(\mathrm{A})$ のように融液を速やかに過冷却液体状態を で泠却した後分相の温度領域以上である $1373 \mathrm{~K}$ で等温熱 処理した試料では, 保持時間の経過とともにフッ素金雲母 の結晶化率は増大し, 約 $7.2 \mathrm{ks}$ 後に約 $45 \%$ に達した後一 定となっている。一方, 熱処理 (B)の上うに過冷却液体を 分相の温度領域内の $1173 \mathrm{~K}$ で等温熱処理した試料では, 保持時間の経過とともにフッ素金雲母の結晶化率は増大し ているが， $7.2 \mathrm{ks}$ 後に20\%に達した後では一定である.

\section{N. 考察}

\section{1. フッ素金雲母結晶の成長機構}

Table 2 亿 Fig. 4 亿示したEDAX の結果から求めた各 相における $\mathrm{Si}$ に対する各元素の相対量を示す。スピノー ダル型分相では $\mathrm{Mg}$ の相対量のみが異なる $\mathrm{A}, \mathrm{B}$ 相から成 っている。また，フッ素金雲母結晶ではこれら $\mathrm{A}, \mathrm{B}$ 相に 比べて $\mathrm{Mg}$ の相対量が多く, $\mathrm{Al}$ が少なくなっている.

先に, Fig. 3 で示したようにフッ素金雲母結晶は $\mathrm{Mg}$ が リッチな $\mathrm{A}$ 相より晶出していた。このことは， $\mathrm{A}$ 相内で の $\mathrm{Mg}$ の拡散によりフッ素金雲母の核生成拉よび成長速 度が支配されているためと考兄られる。 

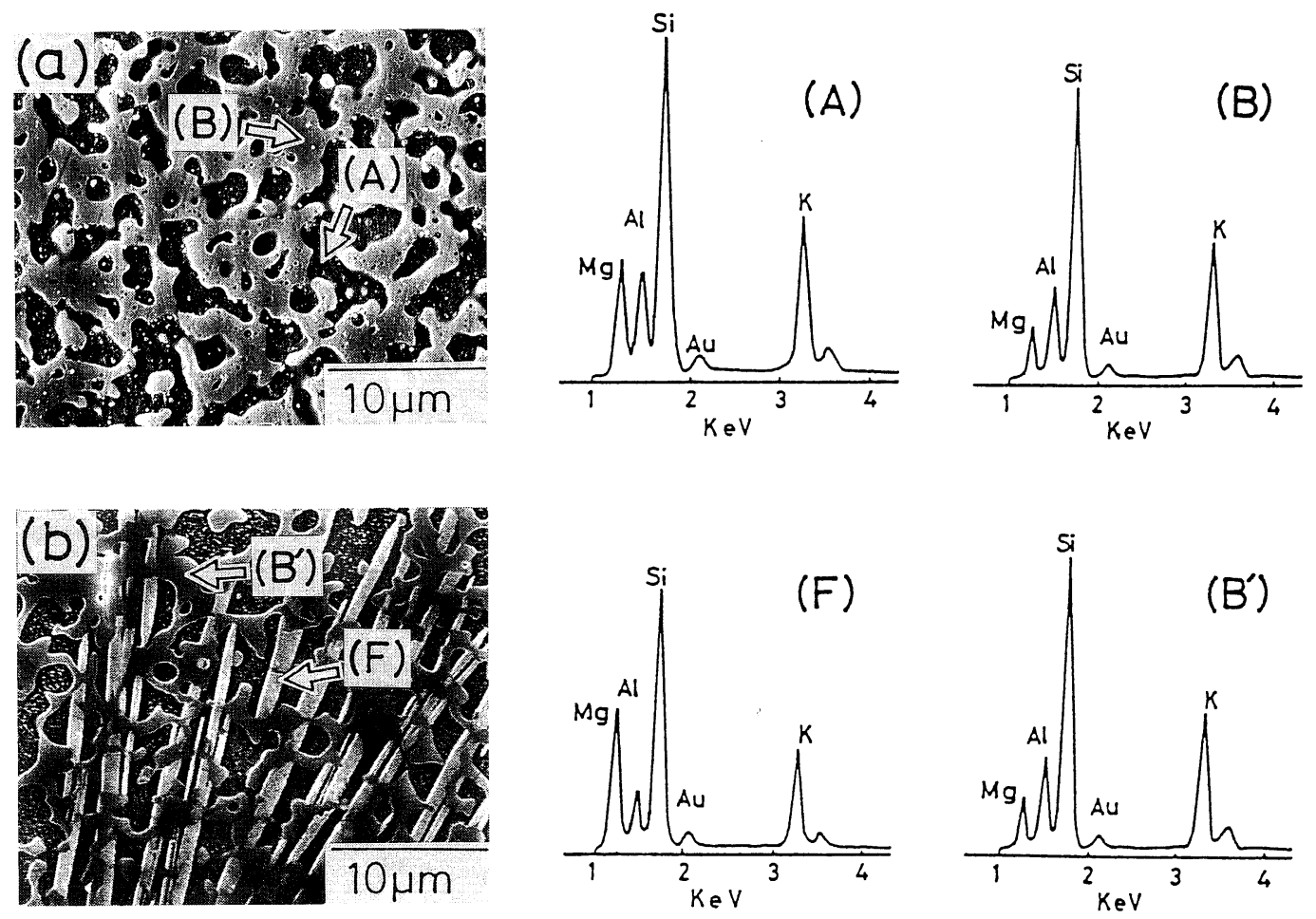

Fig. 4 SEM photographs and EDAX spectra showing (a) spinodal type phase separation and (b) crystallization of fluor-phlogopite.

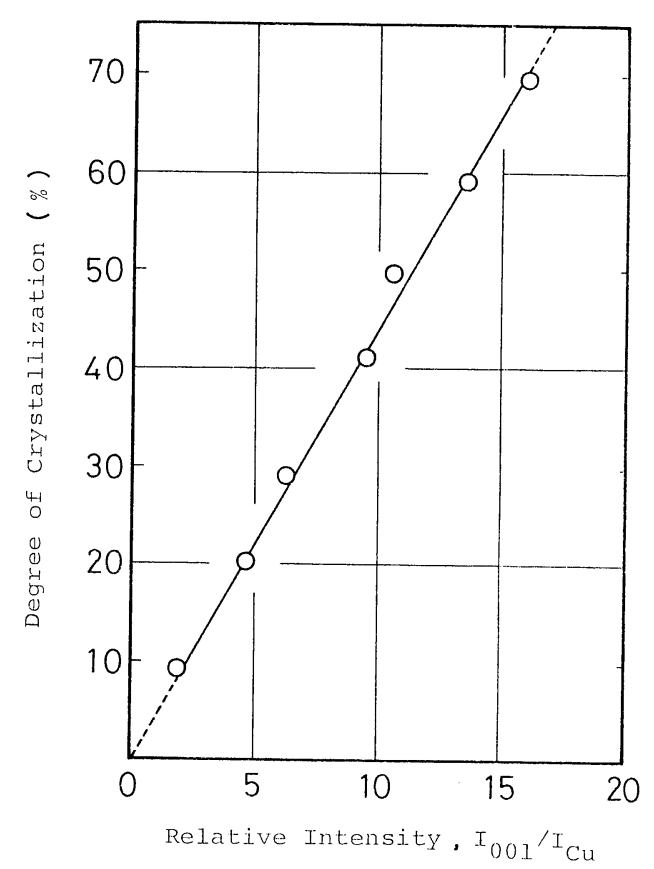

Fig. 5 Relationship between crystallization degree and relative intensity of X-ray diffraction patterns, $I_{001}$ $/ I_{\mathrm{cu}}$.

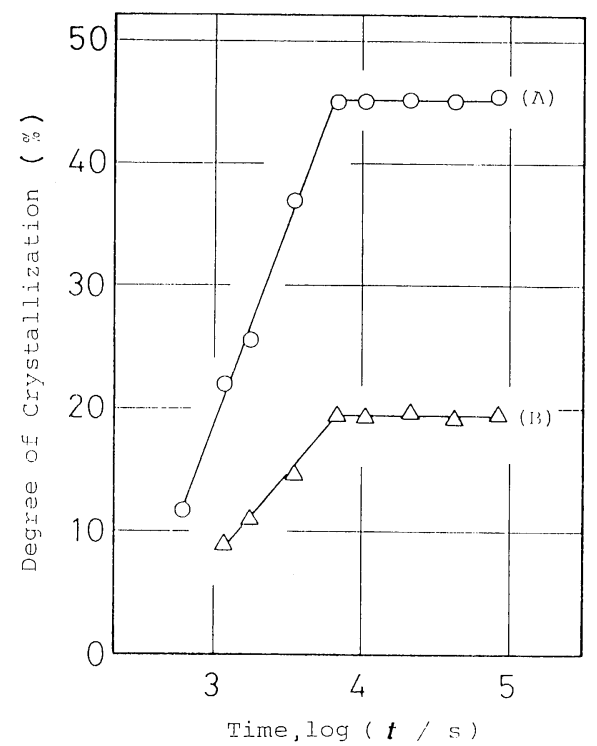

Fig. 6 Time-change of crystallization degree showing the effect of the isothermal heat-treatments, (A) and (B) shown in Fig. 2. 
Table 2 Relative intensity ratio, $\mathrm{K} / \mathrm{Si}, \mathrm{Mg} / \mathrm{Si}$, and $\mathrm{Al} / \mathrm{Si}$ for various phases in the microstructures shown Fig. 3. The ratio was determined from EDAX spectra.

\begin{tabular}{c|c|c|c}
\hline \multirow{2}{*}{ Phases } & \multicolumn{3}{|c}{ Relative intensity ratio } \\
\cline { 2 - 4 } & $\mathrm{K} / \mathrm{Si}$ & $\mathrm{Mg} / \mathrm{Si}$ & $\mathrm{Al} / \mathrm{Si}$ \\
\hline A Phase & 0.477 & 0.349 & 0.326 \\
B Phase & 0.473 & 0.219 & 0.324 \\
Fluor-phlogopite crystal & 0.394 & 0.545 & 0.242 \\
B $^{1}$ Phase & 0.473 & 0.189 & 0.375 \\
\hline
\end{tabular}

フッ素金雲母は， $\left(\mathrm{AlSi}_{3} \mathrm{O}_{10}\right) \mathrm{F}_{2}$ の正四面体がく001〉方向 に, $\mathrm{Mg}\left(\mathrm{SiAlO}_{10}\right) \mathrm{F}_{2}$ の八配位にある $\mathrm{Mg}$ イオンにより密 接に結合され，12配位にある $\mathrm{K}^{+}$イオンによりゆるく結 合しているような結晶構造を持っている(10). したがって, $\mathrm{Mg}$ イオンの拡散によりフッ素金雲母結晶の核生成および 成長速度が決定されるならば，フッ素金雲母は $\mathrm{c}$ 軸であ る〈001〉方向に成長するはずである.

従来ガラス結晶化法による雲母結晶の成長は, 高温で等 温熱処理するほど c 軸方向の成長が促進され(15), また分
相を経由して結晶化させると $\mathrm{a}$ および $\mathrm{b}$ 軸方向への成長 が分相により抑制される(11) ことがわかっている.このた め, ガラス結晶化法により作製したマイカセラミックス中 の分相を経由して析出した雲母結晶は柱状晶を呈してい る(3)(9). Fig. 3 に示すように試料組成の融液を凝固・結晶 化させる過程で得られたフッ素金雲母結晶の形態は柱状晶 である.さらに，Fig. 2 中の熱処理 $(\mathrm{A})$ を施したバルク試 料についてX 線回折を行った結果, 明らかにc 軸である 〈001〉方向へ結晶が優先的に成長していることが確認され た。したがって, 融液の凝固過程において晶出したフッ素 金雲母結晶の成長速度は Mgイオンの拡散により決定さ れ，その形態は〈001〉方向に発達した柱状晶をとったもの と考えられる。

\section{2. 分相を利用した熱処理による結晶化}

Fig. 7 にスピノーダル分解型分相の濃度と距離の関係 とスピノーダル分解型分相を利用したフッ素金雲母の結晶 核生成-成長過程を模式的に示す。Zaraycki と Naudin ${ }^{(16)}$ は任意の熱処理温度 $T$ に拈けるスピノーダル分解型分相

$\mathrm{T}_{1}>\mathrm{T}_{2}$
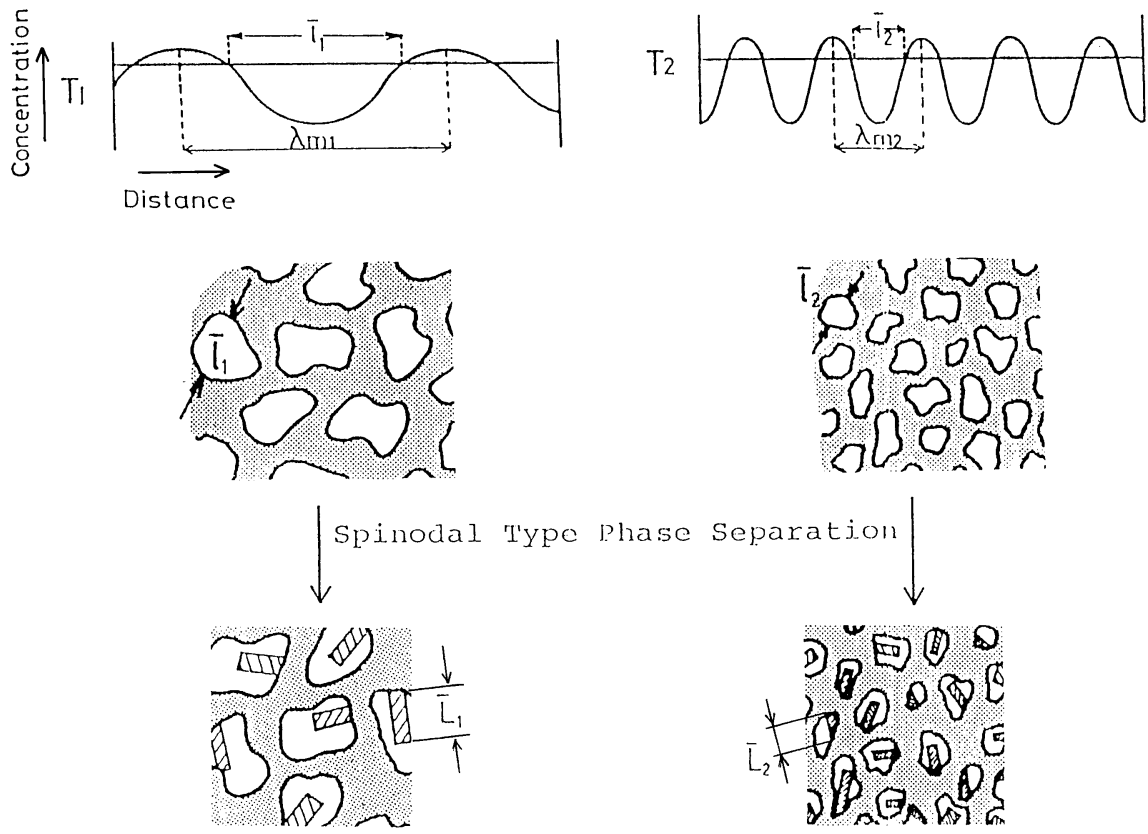

Nucleation and Growth in the

Region of phase separation

Fig. 7 Schematic representation of a nucleation and growth process of fluor-phlogopite platelets after formation of spinodal type phase separation.

$T_{1}, T_{2}$ : Holding temperature in the region of the phase separation,

$\lambda_{\mathrm{m} 1}, \lambda_{\mathrm{m} 2}$ : Spinodal wave length,

$\bar{l}_{1}, \bar{l}_{2}$ : Average width of the phase separation clusters,

$\bar{L}_{1}, \bar{L}_{2}$ : Average diameter of fluor-phlogopite platelets. 
のスピノーダル波長 $\lambda_{\mathrm{m}}$ とスピノーダル温度 $T_{\mathrm{s}}$ からの過 冷却度 $\Delta T_{\mathrm{s}}$ の間には，

$$
1 / \lambda_{\mathrm{m}}=\alpha \Delta T_{\mathrm{s}}
$$

の関係が成方することを報告している。ここで $\alpha$ は比例 定数， $\Delta T_{\mathrm{s}}=T_{\mathrm{s}}-T$ である。式(1)より，スピノ一ダル 温度 $T_{\mathrm{s}}$ からの過椧却度 $\Delta T_{\mathrm{s}}$ ，すなわ台分相領域内の保持 温度 $T$ によりスピノーダル波長 $\lambda_{\mathrm{m}}$ が決定され，本研究に おいてもFig. 7 に示すよらに，分相領域内の保持温度 $T$ が低温であるほどスと゚ノーダル波長に対応する分相の平均 幅夏が小さくなった．Fig. 3からわかるよらにフッ素金需

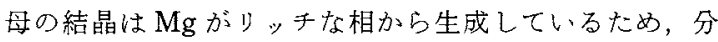
相が生成した状態でフッ素金雲母の結晶核が生成すると分 相の平均幅とその数に依存した微細な結晶が多数発生す る. すな⿰七分相領域内の保持温度 $T$ が低温で過冷却度

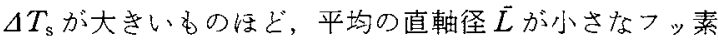
金雲母の䧶結晶が得られる。

Fig. 8 和よび 9 に分相領域内の $1173,1123,1073$ おび $1023 \mathrm{~K}$ の各温度でフッ素金雲母の微結晶を生成させる等 温熱処理を行った試料について分相の平均幅 $\bar{l}$ と $\Delta T_{\mathrm{s}}^{-1}$ の 関係および分相の平均幅 $\bar{l} と 7 ッ$ 素金雲母結晶の平均の長 軸径 $\bar{L}$ との関係をそれぞれ示す。分相の平均幅 $\bar{l}$ とッ 素金雲母結晶の平均の直軸径は $\bar{L}$ は SEM 写真から測定 した。また、Fig. 8 中の破線は実測のスピノーダル温度 $T_{\mathrm{s}}$ とて $1253 \mathrm{~K}$ を用いて，式(1)に叔て $\alpha=1$ と仮 定して求めたスピノーダル波長 $\lambda_{\mathrm{m}}$ と $\Delta T_{\mathrm{s}}^{-1}$ の関係である。

Fig. 8 上り分相の平均幅 (1)から求まるスピーノーダル波長 $\lambda_{\mathrm{m}}$ より当小さくなっ ているが， $\Delta T_{\mathrm{s}}^{-1}$ との間には直線関係が成立し，分相領域 内の保持温度 $T$ が低温であるほど，分相の平均幅 $\bar{l}$ 小

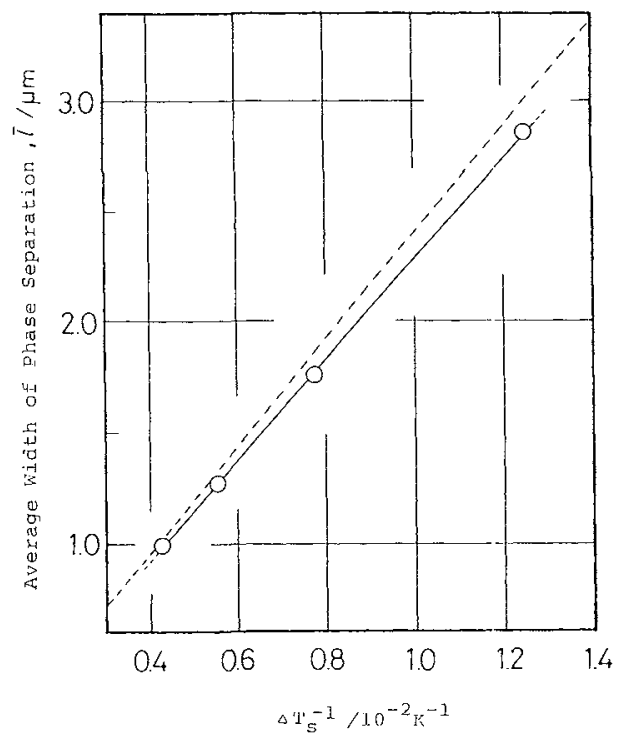

Fig. 8 Relationsphip between average width of phase separation, $L$ and $\Delta T_{\mathrm{s}}{ }^{-1}$.

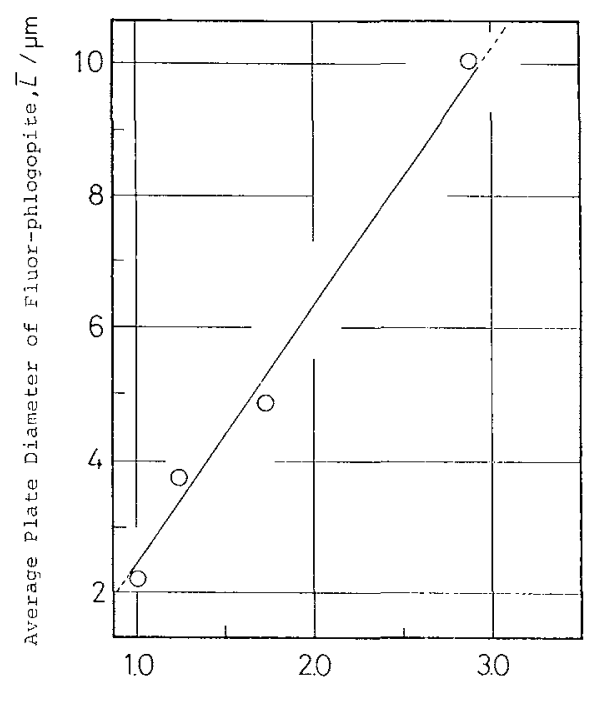

nverage width of phase separation, $l / \mu m$

Fig. 9 Relationship between average width of phase separation, $L$ and average diameter of fluorphlogopite platelets, $L$.

さくなっていることがわかる，李た，Fig.9より分相の平 均幅 $\bar{l} か ゙$ 小さいのほど，すなわち分相領域内の保持温度 $T$ が低温で過冷却度 $\Delta T_{\mathrm{s}}$ が大きいるす伍ど, 平均の直軸 径亡が小さなフッ素金雲母の微結晶が得られることがわ かる。

本研究では，フッ素金雲母の成長速度が $\mathrm{Mg}$ イオンの 搪散により律速されているため, 結晶化に先がけて生じる スピノーダル型分相に拈ける $\mathrm{Mg}$ のッチな $\mathrm{A}$ 相よりこ の結晶は晶出する、したがってこの分相の平均幅を制御す ることによりフッ素金雲母結晶の粒径および形態を制御で きることが明らかとなった。

\section{V. 結言}

フッ素金雲母を晶出させることが可能な融液の凝固・熱 処理過程に和ける CCT 図礼よびTTT図を作成し，フッ 素金雲母結晶の晶出に影響を及活すスと゚ノーダル分解型分 相の存在温度範囲を明らかにした。さらに，TTT図を基 に融液の冷却・熱処理条件がフッ素金雲母の粒径および形 態とその結晶化率に及ぼす影響について検討した。

$1473 \mathrm{~K}$ 以上の高温領域ではフッ素の揮発が激しく, つ ッ素金雲母は生成せずフォルステライトのみが晶出するが， $1473 \mathrm{~K}$ 以下の低温領域で熱処理することによりフッ素金 雲母が晶出した。 $1253 \mathrm{~K}$ 以下にはスピノ一ダル分解型分 相の生成領域が存在した。

融液分分相の温度領域以上である $1373 \mathrm{~K}$ で等温熱処理 した試料に怙けるフッ素金雲母の結晶化率は約 $45 \%$ に達 し，柱状に伸びたその結晶の長軸径は $10 \mu \mathrm{m}$ 以上と粗大 
であった。一方, 融液を分相の生成温度領域内である $1173 \mathrm{~K}$ で等温熱処理した試料におけるフッ素金雲母の結 晶の長軸径は $2 \sim 4 \mu \mathrm{m}$ と比較的微細であるが, 結晶化率 は20\%程度と少なかった。

分相領域内である $1023 \sim 1173 \mathrm{~K}$ での熱処理で，スピ， 一ダル型分相の平均幅を制御することでフッ素金雲母結晶 の粒径および形態を制御できることが明らかになった。

\section{文献}

（1）牧島亮男：機能性ガラス入門，アグネ，(1984), 57 ; 泉谷徹朗 : 新しいガラスとその物性, 経営システム 研究所, (1985), 112.

(2) M. Hirao: Ceram. Bull., 55(1976), 788.

( 3 ) D. G. Grossman: J. Amer. Ceram. Soc., 55 (1972), 446.

（4）田草川信雄, 小久保正, 田代 仁: 窯業協会誌, 89 (1981), 607.
(5) 牧島亮男: セラミックス, 23(1988), 199.

（6）長澤敬之助：粘土ハンドブック，日本粘土学会編， 技報堂出版，（1987）, p. 236.

（7）松尾泰明, 武部博倫, 太田能生, 森永健次 : 資源 素材学会誌, 105 (1989), 1067.

（8）武部博倫, 森永健次：日本金属学会誌, 54(1990), 556.

（９）コーニング社カタログ：石原産業(侏).

(10) S. Strnad: Glass-Ceramic Materials, Elsevier, (1986), 108.

(11) S. M. Ohlberg: J. Amer. Ceram. Soc., 45(1962), 170.

（12）田草川信雄, 斎藤 肇 : 割業協会誌, 78(1970), 92.

（13）森永健次, 太田能生, 柳ヶ瀬 勉：日本金属学会誌, $\mathbf{5 0}(1986), 907$.

（14）野田稲吉, 松下 徹：工業化学雑誌, 51(1947), 83.

（15）松下 徹, 白鳥昌之, 綱島 群, 小平向紘平: 搳業 協会誌, 90(1982), 163.

(16) J. Zaraycki and F. Naudin: J. Non-cryst. Solids, 1(1969), 218. 